\title{
Race-associated biological differences among luminal $A$ and basal-like breast cancers in the Carolina Breast Cancer Study
}

\author{
Humberto Parada Jr ${ }^{1} \mathbb{D}$, Xuezheng Sun², Jodie M. Fleming ${ }^{3}$, ClarLynda R. Williams-DeVane ${ }^{3}$, Erin L. Kirk², \\ Linnea T. Olsson², Charles M. Perou ${ }^{4}$, Andrew F. Olshan ${ }^{2}$ and Melissa A. Troester ${ }^{2 *}$
}

\begin{abstract}
Background: We examined racial differences in the expression of eight genes and their associations with risk of recurrence among 478 white and 495 black women who participated in the Carolina Breast Cancer Study Phase 3.

Methods: Breast tumor samples were analyzed for PAM50 subtype and for eight genes previously found to be differentially expressed by race and associated with breast cancer survival: ACOX2, MUC1, FAM177A1, GSTT2, PSPH, PSPHL, SQLE, and TYMS. The expression of these genes according to race was assessed using linear regression and each gene was evaluated in association with recurrence using Cox regression.

Results: Compared to white women, black women had lower expression of MUC1, a suspected good prognosis gene, and higher expression of GSTT2, PSPHL, SQLE, and TYMS, suspected poor prognosis genes, after adjustment for age and PAM50 subtype. High expression (greater than median versus less than or equal to median) of FAM177A1 and PSPH was associated with a $63 \%$ increase (hazard ratio $(H R)=1.63,95 \%$ confidence interval $(C \mathrm{Cl})=1$. 09-2.46) and $76 \%$ increase $(H R=1.76,95 \% \mathrm{Cl}=1.15-2.68)$, respectively, in risk of recurrence after adjustment for age, race, PAM50 subtype, and ROR-PT score. Log 2 -transformed SQLE expression was associated with a 20\% increase $(\mathrm{HR}=1.20,95 \% \mathrm{Cl}=1.03-1.41)$ in recurrence risk after adjustment. A continuous multi-gene score comprised of eight genes was also associated with increased risk of recurrence among all women ( $\mathrm{HR}=1.11,95 \% \mathrm{Cl}=1.04-1.19)$ and among white $(H R=1.14,95 \% \mathrm{Cl}=1.03-1.27)$ and black $(H R=1.11,95 \% \mathrm{Cl}=1.02-1.20)$ women.
\end{abstract}

Conclusions: Racial differences in gene expression may contribute to the survival disparity observed between black and white women diagnosed with breast cancer.

Keywords: Breast cancer, Gene expression, Disparities, Recurrence

\section{Background}

Historically, white women have had higher incidence rates of breast cancer compared to black women; however, in recent years incidence rates among white and black women have converged [1]. Mortality rates, on the other hand, remain higher among black women, and rates have continued to diverge despite notable improvements in survival in both races since 1990 [2]. Environmental and other factors including socio-economic status, access to

\footnotetext{
* Correspondence: troester@unc.edu

${ }^{2}$ Department of Epidemiology, University of North Carolina at Chapel Hill, Campus Box 7435, Chapel Hill, NC 27599, USA

Full list of author information is available at the end of the article
}

and quality of care, and delays in treatment have been cited as potential explanations of the survival disparity, as have biological factors [3]. Previous research indicates that even among estrogen receptor (ER)-positive and HER2negative breast cancers, which have more favorable outcomes [4], black women have higher mortality rates compared to white women [5]. Recent work highlighted racial differences in risk of recurrence (ROR) scores among $\mathrm{ER}^{+} / \mathrm{HER} 2^{-}$breast cancers [6, 7], but biological differences in tumors between black and white women are only just beginning to be understood.

Several studies have used whole genome expression data to screen for racial differences in tumors [8-11], including our own recent findings [12]. In that study, we examined 
biological differences by race among luminal A and basallike breast cancers using publicly available data, and identified several genes including $A C O X 2, C R Y B B 2, M U C 1$, $P S P H, S Q L E$, and TYMS that were differentially expressed by race and that were associated with differences in survival [12]. A limitation of our prior study was the small study population, with data from only 108 Caucasian and 57 African-American women. Herein, we expand this analysis to validate our previous findings in approximately 1000 cases, half of whom are black women, within a larger population-based context. Specifically, we sought to estimate differences in the expression of two suspected good prognosis genes (ACOX2 and MUC1) and six suspected poor prognosis genes (FAM177A1, GSTT2, PSPH, PSPHL, $S Q L E$, and TYMS) by race, and to examine their associations with risk of breast cancer recurrence.

\section{Methods}

\section{Study population}

This study uses data from the Carolina Breast Cancer Study Phase 3 (CBCS3), a population-based study of 3000 women conducted in 24 counties in eastern and central North Carolina from 2008-2013. Recruitment and data collection procedures for CBCS3 and prior study phases appear elsewhere [13]. In brief, women aged 20-74 years residing in the 24 counties and diagnosed with first primary invasive breast cancer were identified using rapid case ascertainment in collaboration with the NC Central Cancer Registry. After determination of study eligibility, sampling was performed to ensure adequate representation of various subgroups (i.e., young and African-American women). After informed consent was obtained, all participants completed an interviewer-administered questionnaire, provided blood samples, and provided written consent for retrieval of medical records and paraffin-embedded tumor blocks.

\section{Tumor gene expression profiling and molecular subtyping}

Procedures for tumor gene expression profiling of the 1013 of 3000 women enrolled in the CBCS3 have been previously published [6]. In brief, RNA was isolated from cores using the Qiagen RNeasy FFPE kit and protocol, with $95 \%$ of tumors producing quantifiable RNA. The majority $(98.2 \%)$ of samples were obtained before neoadjuvant chemotherapy treatment. Samples were randomized to batches for RNA extraction and analyses. In total, 1122 samples from 1042 cases from CBCS3 were analyzed for the PAM50 assay and for the expression of an additional 150 genes using the NanoString nCounter gene expression system [14]. The PAM50 predictor [15] was used to categorize breast tumors into intrinsic subtype as luminal A, luminal B, HER2-enriched, basal-like, and normal-like, and to calculate the ROR score with proliferation (ROR-P) and tumor size (ROR-PT) included. Probes for nine genes identified by D'Arcy et al. were included: $A C O X 2$, CRYBB2, MUC1, FAM177A1, GSTT2, PSPH, PSPHL, SQLE, and TYMS [12].

Quality control was conducted using the NanoStringNorm package in R. Samples with poor quality were identified using the following criteria: (1) the ratio of the geometric mean expression levels of six positive controls of a sample to the average geometric means of the six positive controls across all samples fell outside the range of $0.3-3$; (2) the expression level of $90 \%$ of endogenous genes was lower than the mean $(+3 \mathrm{SD})$ of negative controls; and (3) the geometric mean of the reference genes of a sample was greater than 3 SDs from the average geometric means of the reference genes across all batches. Of the 1122 samples, 39 did not pass quality control. We further excluded 70 duplicate samples with lower quality gene expression data, resulting in an analytic gene expression sample of 1013. Of the nine genes of initial interest in the current study, the expression of one (CRYBB2) was below the geometric mean of negative controls in $>60 \%$ of samples and was not considered further. The raw RNA counts were normalized using the geometric mean of the six positive control genes and then $\log _{2}$-transformed for analyses. Among the 1013 women with available gene expression data, we excluded all women who self-identified as non-black or non-Caucasian white, including seven American-Indian, 13 Asian, and 20 women of 'other' races, resulting in an analytic sample of 478 white and 495 black women (see Additional file 1: Table S1) for participant characteristics).

\section{Breast cancer recurrence}

The time from breast cancer diagnosis to the first breast cancer recurrence was obtained from the medical records. Among the 973 women with available gene expression data, we identified 114 women with at least one recurrence during a median follow-up of 5.07 years (range $=0.39-8.22$ years). Approximately 9\% of white women and $15 \%$ of black women had at least one recurrence during the follow-up period.

\section{Statistical analysis}

We first examined associations between gene expression and a range of participant demographics, reproductive factors, and clinical characteristics using linear regression and independent sample $t$ tests. Based on likelihood ratio tests from age-adjusted linear regression models, with the exception of ER status, there were no significant gene expressionby-covariate interactions. Therefore, results from the independent sample $t$ tests based on all women are reported in Additional file 1: Table S1), and age-adjusted RNA counts by race and ER status are reported separately in Additional file 1: Table S2). We then examined race-associated gene expression of the eight genes overall, and by luminal $\mathrm{A}$ and 
basal-like breast cancer subtype using linear regression. In separate models, we regressed the normalized $\log _{2}$-transformed expression of each of the eight genes on: race (black vs white), study design variables (age at diagnosis in years, which was used for sampling; and codeset, which varied between Nanostring batches), and PAM50 subtype (luminal A, luminal B, HER2-enriched, basal-like, and normal-like), as appropriate. The covariate-adjusted $\beta$ coefficients, representing the $\log _{2}$ (relative difference in gene expression among black women relative to white women), and the corresponding 95\% confidence limits from the linear regression models were back-transformed (i.e., $10^{\left(\log (2)^{*} \beta\right)}$ ) to obtain the relative difference in gene expression.

We dichotomized gene expression at the median (i.e., $\leq$ median = low, and $>$ median $=$ high expression) for each gene and, among the 938 women with breast cancer stages I-III, examined unadjusted associations with risk of recurrence using the Kaplan-Meier survival function. Overall, and by race, and among women with $\mathrm{ER}^{+} / \mathrm{HER} 2^{-}$breast cancer, we used Cox regression to estimate hazard ratios (HRs) and 95\% confidence intervals (CIs) for the associations between dichotomized as well as continuous $\log _{2}$ transformed gene expression adjusted for age, race, codeset, PAM50 subtype, and ROR-PT score (low, medium, and high), as appropriate. Although breast cancer subtype could potentially mediate the associations between gene expression and breast cancer recurrence, we were interested in understanding these adjusted associations rather than assuming a causal model. We evaluated the joint effects of all eight genes on risk of recurrence by creating a multi-gene race-associated expression (MRE) score. To compute the score, we applied the method of D'Arcy et al. [12] wherein we assigned individual scores of -1 or +1 to each of the eight genes. For six of the eight genes (FAM177A1, GSTT2, $P S P H, P S P H L, S Q L E$, and TYMS), expression below the median was assigned a risk score of -1 indicating lower risk of recurrence, and expression above the median was assigned a score of +1 indicating higher risk of recurrence. Given the inverse associations between survival and expression of $A C O X 2$ and $M U C 1$, for these two genes expression below the median was assigned a score of +1 and expression above the median was assigned a score of -1 . We summed the individual gene risk scores resulting in an MRE score ranging from -8 to +8 , with higher scores indicating higher risk of recurrence, and also categorized the MRE score as -8 to -2 (low), -1 to 3 (medium), and 4 to 8 (high recurrence risk). We conducted all analyses using SAS version 9.4 (SAS Institute Inc., Cary, NC, USA).

\section{Results}

In this subsample of women from $\mathrm{CBCS} 3$, there were approximately equal proportions of black (51\%) and white (49\%) breast cancer patients (Additional file 1: Table S1). Women were approximately 52 years of age on average, and the majority were postmenopausal (57\%), and diagnosed with stage I/II (84\%) and grade I/II (52\%) tumors. By PAM50 classification, the majority of tumors were luminal A (38\%), followed by basal-like (25\%), luminal B (20\%), HER2-enriched (12\%), and normal-like (5\%). As previously reported in CBCS3 [6] and elsewhere [5, 7], black women of all ages had a higher frequency of basal-like (33.9\% versus 16.7\%) and HER2-enriched (13.3\% versus 10.0\%) cancers, and lower frequency of luminal A breast cancers (29.5\% versus 47.3\%). Few participant demographic and reproductive factor characteristics were consistently associated with gene expression. On the other hand, the expression of most genes was associated with clinicopathological factors including tumor grade, tumor size, ER and progesterone receptor (PR) status, and PAM50 subtype (Additional file 1: Tables S1 and S2).

\section{Racial differences in gene expression}

Overall, black women had lower expression of MUC1, a good prognosis gene, and higher expression GSTT2, $P S P H L, S Q L E$, and TYMS, poor prognosis genes, after adjustment for age, codeset, and PAM50 subtype (Table 1). The largest difference in expression was for $P S P H L$, of which black women had expression levels that were more than double those in white women (relative expression $=2.38,95 \% \mathrm{CI}=2.11-2.67)$. Racial patterns in expression of these five genes were similar in direction and magnitude when restricted to women with luminal A breast tumors; however, among women with basal-like tumors, only GSTT2 and PSPHL were differentially expressed by race.

\section{Gene expression and risk of recurrence}

As shown in Fig. 1, among stage I-III women of both races, low (vs high) expression of $A C O X 2$ and $M U C 1$ was associated with increased risk of recurrence (logrank $\chi^{2} P=0.015$ and $P<0.001$, respectively). In contrast, high (vs low) expression of PSPH $(P=0.021)$, PSPHL $(P=0.001)$, SQLE $(P=0.012)$ and TYMS $(P<$ $0.001)$ were each associated with increased risk of recurrence. Most associations with recurrence persisted after adjustment for study design variables (Table 2). Only FAM177A1, PSPH, and SQLE remained statistically significant after further adjustment for PAM50 subtype and ROR-PT score. High expression of FAM177A1 and PSPH was associated with $63 \%(\mathrm{HR}=$ 1.63, 95\% $\mathrm{CI}=1.09-2.46)$ and $76 \% \quad(\mathrm{HR}=1.76$, 95\% $\mathrm{CI}=1.15-2.68)$ increases, respectively, in risk of recurrence. Dichotomized SQLE expression was not associated with risk of recurrence; however, continuous $\log _{2}$-transformed SQLE expression was associated with a $20 \%$ increase $(\mathrm{HR}=1.20,95 \% \mathrm{CI}=1.03-1.41)$ in recurrence risk. 
Table 1 Racial differences in gene expression among white $(n=478)$ and black $(n=495)$ women, overall and by breast cancer subtype, from CBCS Phase 3, 2008-2013

\begin{tabular}{|c|c|c|c|c|c|c|}
\hline \multirow[b]{2}{*}{ Gene } & \multicolumn{2}{|l|}{ Overall $(n=973)$} & \multicolumn{2}{|l|}{ Luminal A $(n=372)$} & \multicolumn{2}{|l|}{ Basal-like $(n=248)$} \\
\hline & Relative expression $(95 \% \mathrm{Cl})^{\mathrm{a}}$ & $P$ & Relative expression $(95 \% \mathrm{Cl})^{\mathrm{a}}$ & $P$ & Relative expression $(95 \% \mathrm{Cl})^{\mathrm{a}}$ & $P$ \\
\hline $\operatorname{ACO} 2$ & $0.99(0.87-1.12)$ & 0.849 & $1.00(0.86-0.96)$ & 0.958 & $1.12(0.79-1.58)$ & 0.539 \\
\hline MUCl & $0.72(0.62-0.83)$ & $<0.001$ & $0.68(0.56-0.82)$ & $<0.001$ & $0.81(0.58-1.12)$ & 0.202 \\
\hline FAM177A1 & $1.00(0.94-1.06)$ & 0.941 & $1.00(0.94-1.07)$ & 0.962 & $0.98(0.80-1.20)$ & 0.834 \\
\hline GSTT2 & $1.41(1.19-1.68)$ & $<0.001$ & $1.43(1.10-1.85)$ & 0.008 & $1.58(1.07-2.32)$ & 0.020 \\
\hline PSPH & $1.00(0.91-1.10)$ & 0.984 & $0.98(0.88-1.10)$ & 0.780 & $1.13(0.87-1.46)$ & 0.349 \\
\hline PSPHL & $2.38(2.11-2.67)$ & $<0.001$ & $2.33(1.95-2.79)$ & $<0.001$ & $1.77(1.39-2.24)$ & $<0.001$ \\
\hline SQLE & $1.15(1.04-1.27)$ & 0.007 & $1.19(1.05-1.35)$ & 0.006 & $0.98(0.76-1.27)$ & 0.868 \\
\hline TYMS & $1.20(1.11-1.29)$ & $<0.001$ & $1.24(1.12-1.38)$ & $<0.001$ & $1.08(0.92-1.26)$ & 0.345 \\
\hline
\end{tabular}

RNA counts were normalized $\log _{2}$-transformed prior to analysis

$\mathrm{Cl}$ confidence interval

${ }^{\text {a }}$ Relative expression comparing black versus white (referent) women; relative expression is adjusted for age, codeset, and PAM50 subtype, as appropriate

We next stratified these survival relationships by race. Patterns of recurrence were similar when adjusting for study design factors only. However, after further adjustment for PAM50 subtype and ROR-PT score, most associations among white women were weaker than those among black women, with the exception of PSPH which was stronger in white $(\mathrm{HR}=2.04,95 \% \mathrm{CI}=1.00-4.15)$ than black $(\mathrm{HR}=1.69,95 \% \mathrm{CI}=1.00-2.85)$ women. Among black women, high (vs low) expression of FAM177A1 was associated with a $73 \%$ increase $(\mathrm{HR}=$ $1.73,95 \% \mathrm{CI}=1.04-2.87)$ in risk of recurrence in the fully adjusted model.

Breast cancer mortality disparities are greatest among women diagnosed with $\mathrm{ER}^{+} / \mathrm{HER}^{-}$breast cancer stages I-III; therefore, we assessed survival associations among patients with this clinical subtype. In association with $\log _{2}$-unit increase in expression of $M U C 1$, white women had reduced risk of recurrence $(\mathrm{HR}=0.81,95 \% \mathrm{CI}=$ 0.65-1.01), but MUC1 levels were not associated with recurrence in black women $(\mathrm{HR}=0.98,95 \% \mathrm{CI}=0.81-$ 1.20). High (vs low) expression of PSPH and TYMS was associated with more than twice the risk of recurrence in black (PSPH HR $=2.25,95 \% \mathrm{CI}=0.99-5.13 ;$ TYMS $\mathrm{HR}=2.64,95 \% \mathrm{CI}=1.00-6.95)$, but not white $(P S P H$ $\mathrm{HR}=1.90,95 \% \mathrm{CI}=0.73-4.95 ;$ TYMS HR $=0.51,95 \%$ $\mathrm{CI}=0.19-1.43$ ) women (Additional file 1: Table S3).

The MRE score, which evaluated the additive effects of all eight genes, was associated with increased risk of recurrence among all women $(\mathrm{HR}=1.11,95 \% \mathrm{CI}=1.04-$ 1.19) and among white $(\mathrm{HR}=1.14,95 \% \mathrm{CI}=1.03-1.27)$ and black ( $\mathrm{HR}=1.11,95 \% \mathrm{CI}=1.02-1.20)$ women after covariate adjustment, including adjustment for PAM50 subtype and ROR-PT score. Among women of both races, the risk of recurrence for women with the highest MRE scores (4 to 8), relative to those with the lowest scores $(-8$ to -2$)$, was associated with a $110 \%$ increase $(\mathrm{HR}=2.10,95 \% \mathrm{CI}=1.22-3.62)$ in recurrence risk. In the subgroup of women with $\mathrm{ER}^{+} / \mathrm{HER}^{-}$breast cancer, the MRE score was associated with a $15 \%$ increase in risk in black women $(\mathrm{HR}=1.15,95 \% \mathrm{CI}=1.00-1.31)$, but not white women $(\mathrm{HR}=1.08,95 \% \mathrm{CI}=0.95-1.23)$.

\section{Discussion}

Previously reported race and survival-associated genes including MUC1, GSTT2, PSPHL, SQLE, and TYMS were associated with race in this population-based study of women diagnosed with breast cancer. Except for FAM177A1 and GSTT2, the genes we examined in this study were associated with risk of recurrence in unadjusted models. Of the genes differentially expressed by race, SQLE expression as a continuous measure was associated with increased risk of breast cancer recurrence, even after adjustment for breast cancer subtype and ROR score. Additionally, a multi-gene score comprised of all eight genes examined in this study was strongly associated with recurrence risk among all women and among black women diagnosed with $\mathrm{ER}^{+} / \mathrm{HER}^{-}$breast cancer.

Our findings are consistent with prior studies reporting lower expression of $M U C 1$ and higher expression of GSTT2, PSPHL, SQLE, and TYMS among black women compared to white women [9-12]. MUC1 expression was positively associated with lower grade, smaller tumor size, and positive ER/PR status in our study and in a previous study [16]; however, expression was not associated with recurrence among black women after adjustment for PAM50 subtype, although there was a suggestive inverse association with recurrence among white women. MUC1, which is part of a large family of mucin glycoproteins, is involved with cell signaling and cell-cell and cell-matrix adhesion [17], and may impact breast cancer recurrence via these pathways or by directly binding to and activating $\mathrm{ER} \alpha$ [18]. In contrast to previous studies, in our study PSPH and ACOX2 were not differentially expressed by race, although $P S P H$, but 


\section{A Good Prognosis Genes}
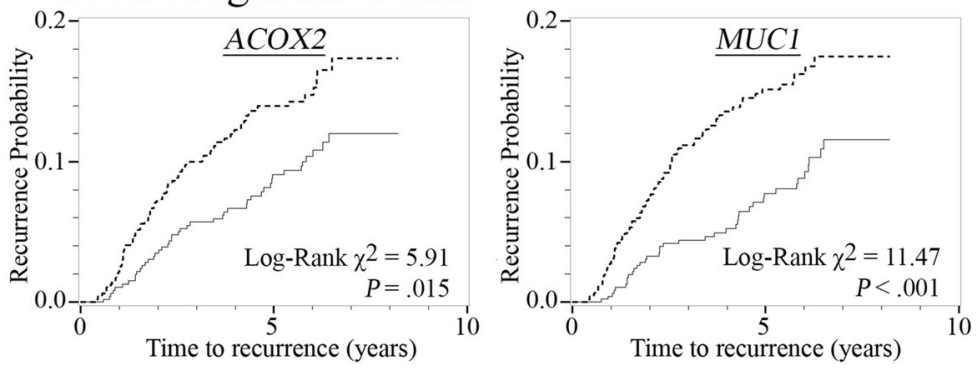

\section{B Poor Prognosis Genes}
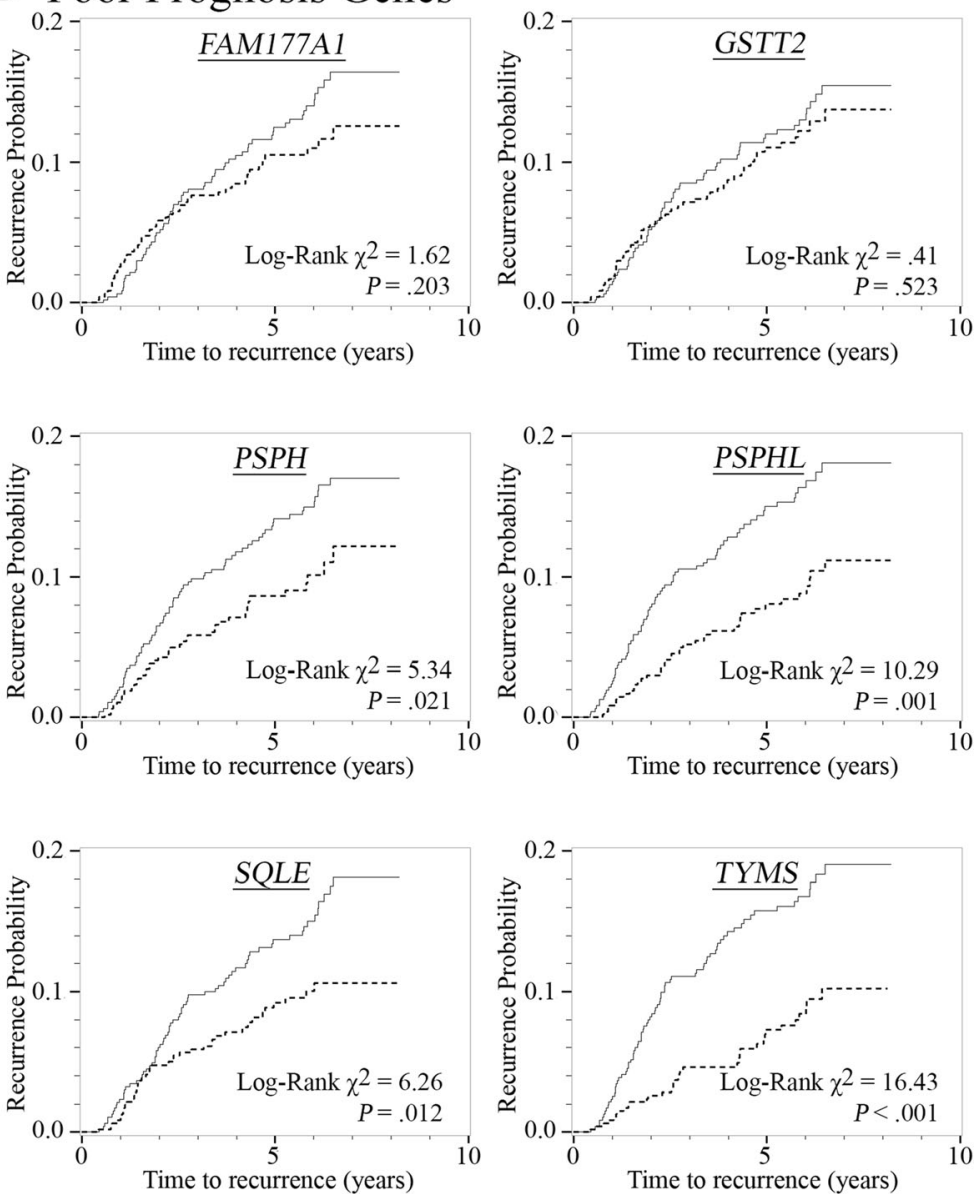

Fig. 1 Risk of recurrence by dichotomized gene expression (dashed line= expression below median; solid line = expression above median) from CBCS Phase 3, 2008-2013 ( $n=938$ ). a Genes previously found to be inversely associated with breast cancer mortality, and b genes previously found to be positively associated with breast cancer mortality

not $A C O X 2$, expression was associated with recurrence. Interestingly, recent evidence suggests that racial differences in the expression of PSPHL may be a consequence of a 30-kb deletion from chromosome $7 \mathrm{p} 11$, including the promoter and first three of four exons of PSPHL, effectively eliminating PSPHL expression, more frequently found among individuals of African ancestry [19]. Although we did not examine PSPHL polymorphisms, our findings may reflect underlying genetic differences. Whereas the study by Rummel and colleagues [19] found no association between PSPHL loss or retention and pathological characteristics, in our study, PSPHL expression was associated with grade, tumor size, ER/PR status, and breast cancer PAM50 subtype [19].

$S Q L E$ expression was higher in tumors of black women compared to white women, and was associated with more 
Table 2 Gene expression and risk of recurrence, overall and by race, from CBCS Phase 3, 2008-2013

\begin{tabular}{|c|c|c|c|c|c|c|c|c|c|}
\hline \multirow[b]{2}{*}{ Gene } & \multicolumn{3}{|c|}{ Overall $(n=938)$} & \multicolumn{3}{|c|}{ White $(n=465)$} & \multicolumn{3}{|l|}{ Black $(n=473)$} \\
\hline & Recurrence/n & $\mathrm{HR}^{\mathrm{b}}(95 \% \mathrm{Cl})$ & $\overline{\mathrm{HR}^{\mathrm{C}}(95 \% \mathrm{Cl})}$ & Recurrence/n & $\mathrm{HR}^{\mathrm{b}}(95 \% \mathrm{Cl})$ & $\operatorname{HR}^{C}(95 \% \mathrm{Cl})$ & Recurrence/n & $\mathrm{HR}^{\mathrm{b}}(95 \% \mathrm{Cl})$ & $\overline{\operatorname{HR}^{\mathrm{C}}(95 \% \mathrm{Cl})}$ \\
\hline \multicolumn{10}{|l|}{ ACOX2 } \\
\hline$\leq$ Median & $66 / 469$ & 1.00 & 1.00 & $25 / 206$ & 1.00 & 1.00 & $41 / 263$ & 1.00 & 1.00 \\
\hline$>$ Median & $45 / 469$ & $\begin{array}{l}0.65 \\
(0.44-0.96)\end{array}$ & $\begin{array}{l}0.88 \\
(0.58-1.32)\end{array}$ & $17 / 259$ & $\begin{array}{l}0.44 \\
(0.24-0.83)\end{array}$ & $\begin{array}{l}0.68 \\
(0.35-1.32)\end{array}$ & $28 / 210$ & $\begin{array}{l}0.84 \\
(0.51-1.37)\end{array}$ & $\begin{array}{l}1.09 \\
(0.65-1.82)\end{array}$ \\
\hline $\log _{2}$ & & $\begin{array}{l}0.94 \\
(0.83-1.06)\end{array}$ & $\begin{array}{l}1.05 \\
(0.93-1.18)\end{array}$ & & $\begin{array}{l}0.81 \\
(0.64-1.01)\end{array}$ & $\begin{array}{l}0.99 \\
(0.79-1.23)\end{array}$ & & $\begin{array}{l}1.01 \\
(0.88-1.17)\end{array}$ & $\begin{array}{l}1.09 \\
(0.95-1.25)\end{array}$ \\
\hline \multicolumn{10}{|l|}{ MUC1 } \\
\hline$\leq$ Median & $72 / 474$ & 1.00 & 1.00 & $24 / 179$ & 1.00 & 1.00 & $48 / 295$ & 1.00 & 1.00 \\
\hline$>$ Median & $39 / 464$ & $\begin{array}{l}0.57 \\
(0.38-0.85)\end{array}$ & $\begin{array}{l}0.89 \\
(0.57-1.40)\end{array}$ & $18 / 286$ & $\begin{array}{l}0.38 \\
(0.21-0.71)\end{array}$ & $\begin{array}{l}0.62 \\
(0.30-1.26)\end{array}$ & $21 / 178$ & $\begin{array}{l}0.71 \\
(0.43-1.19)\end{array}$ & $\begin{array}{l}1.04 \\
(0.58-1.86)\end{array}$ \\
\hline $\log _{2}$ & & $\begin{array}{l}0.87 \\
(0.79-0.95)\end{array}$ & $\begin{array}{l}0.97 \\
(0.87-1.08)\end{array}$ & & $\begin{array}{l}0.77 \\
(0.67-0.88)\end{array}$ & $\begin{array}{l}0.88 \\
(0.74-1.04)\end{array}$ & & $\begin{array}{l}0.93 \\
(0.83-1.05)\end{array}$ & $\begin{array}{l}1.02 \\
(0.89-1.18)\end{array}$ \\
\hline \multicolumn{10}{|l|}{ FAM177A1 } \\
\hline$\leq$ Median & $47 / 468$ & 1.00 & 1.00 & $16 / 211$ & 1.00 & 1.00 & $31 / 257$ & 1.00 & 1.00 \\
\hline > Median & $64 / 470$ & $\begin{array}{l}1.32 \\
(0.89-1.95)\end{array}$ & $\begin{array}{l}1.63 \\
(1.09-2.46)\end{array}$ & $26 / 254$ & $\begin{array}{l}1.05 \\
(0.53-2.06)\end{array}$ & $\begin{array}{l}1.37 \\
(0.69-2.73)\end{array}$ & $38 / 216$ & $\begin{array}{l}1.44 \\
(0.89-2.35)\end{array}$ & $\begin{array}{l}1.73 \\
(1.04-2.87)\end{array}$ \\
\hline $\log _{2}$ & & $\begin{array}{l}1.14 \\
(0.86-1.50)\end{array}$ & $\begin{array}{l}1.33 \\
(1.01-1.73)\end{array}$ & & $\begin{array}{l}1.14 \\
(0.68-1.92)\end{array}$ & $\begin{array}{l}1.46 \\
(0.90-2.39)\end{array}$ & & $\begin{array}{l}1.14 \\
(0.81-1.59)\end{array}$ & $\begin{array}{l}1.28 \\
(0.92-1.77)\end{array}$ \\
\hline \multicolumn{10}{|l|}{ GSTT2 } \\
\hline$\leq$ Median & $51 / 471$ & 1.00 & 1.00 & $22 / 250$ & 1.00 & 1.00 & $29 / 221$ & 1.00 & 1.00 \\
\hline > Median & $60 / 467$ & $\begin{array}{l}1.06 \\
(0.72-1.55)\end{array}$ & $\begin{array}{l}1.27 \\
(0.86-1.88)\end{array}$ & $20 / 215$ & $\begin{array}{l}0.97 \\
(0.53-1.78)\end{array}$ & $\begin{array}{l}1.26 \\
(0.68-2.34)\end{array}$ & $40 / 252$ & $\begin{array}{l}1.18 \\
(0.72-1.93)\end{array}$ & $\begin{array}{l}1.36 \\
(0.82-2.26)\end{array}$ \\
\hline $\log _{2}$ & & $\begin{array}{l}1.01 \\
(0.92-1.11)\end{array}$ & $\begin{array}{l}1.07 \\
(0.97-1.18)\end{array}$ & & $0.96(0.82-1.12)$ & $1.03(0.88-1.20)$ & & $\begin{array}{l}1.06 \\
(0.93-1.20)\end{array}$ & $\begin{array}{l}1.11 \\
(0.97-1.26)\end{array}$ \\
\hline \multicolumn{10}{|l|}{ PSPH } \\
\hline$\leq$ Median & $41 / 472$ & 1.00 & 1.00 & $13 / 228$ & 1.00 & 1.00 & $28 / 244$ & 1.00 & 1.00 \\
\hline$>$ Median & $70 / 466$ & $\begin{array}{l}1.71 \\
(1.12-2.61)\end{array}$ & $\begin{array}{l}1.76 \\
(1.15-2.68)\end{array}$ & $29 / 237$ & $\begin{array}{l}1.79 \\
(0.87-3.71)\end{array}$ & $\begin{array}{l}2.04 \\
(1.00-4.15)\end{array}$ & $41 / 229$ & $\begin{array}{l}1.66 \\
(0.98-2.80)\end{array}$ & $\begin{array}{l}1.69 \\
(1.00-2.85)\end{array}$ \\
\hline $\log _{2}$ & & $\begin{array}{l}1.18 \\
(1.00-1.41)\end{array}$ & $\begin{array}{l}1.18 \\
(1.00-1.39)\end{array}$ & & $\begin{array}{l}1.32 \\
(0.95-1.84)\end{array}$ & $\begin{array}{l}1.36 \\
(0.98-1.87)\end{array}$ & & $\begin{array}{l}1.15 \\
(0.94-1.40)\end{array}$ & $\begin{array}{l}1.14 \\
(0.94-1.38)\end{array}$ \\
\hline \multicolumn{10}{|l|}{ PSPHL } \\
\hline$\leq$ Median & $40 / 474$ & 1.00 & 1.00 & $25 / 341$ & 1.00 & 1.00 & $15 / 133$ & 1.00 & 1.00 \\
\hline > Median & $71 / 464$ & $\begin{array}{l}1.52 \\
(0.95-2.44)\end{array}$ & $\begin{array}{l}1.33 \\
(0.83-2.15)\end{array}$ & $17 / 124$ & $\begin{array}{l}1.74 \\
(0.93-3.26)\end{array}$ & $\begin{array}{l}1.53 \\
(0.80-2.92)\end{array}$ & $54 / 340$ & $\begin{array}{l}1.42 \\
(0.72-2.81)\end{array}$ & $\begin{array}{l}1.24 \\
(0.62-2.48)\end{array}$ \\
\hline $\log _{2}$ & & $\begin{array}{l}1.14 \\
(1.00-1.31)\end{array}$ & $\begin{array}{l}1.09 \\
(0.95-1.26)\end{array}$ & & $\begin{array}{l}1.19 \\
(0.96-1.48)\end{array}$ & $\begin{array}{l}1.10 \\
(0.87-1.39)\end{array}$ & & $\begin{array}{l}1.16 \\
(0.97-1.38)\end{array}$ & $\begin{array}{l}1.10 \\
(0.92-1.32)\end{array}$ \\
\hline \multicolumn{10}{|l|}{ SQLE } \\
\hline$\leq$ Median & $41 / 468$ & 1.00 & 1.00 & $17 / 273$ & 1.00 & 1.00 & $24 / 195$ & 1.00 & 1.00 \\
\hline > Median & $70 / 470$ & $\begin{array}{l}1.47 \\
(0.99-2.17)\end{array}$ & $\begin{array}{l}1.09 \\
(0.73-1.64)\end{array}$ & $25 / 192$ & $\begin{array}{l}1.97 \\
(1.06-3.65)\end{array}$ & $\begin{array}{l}1.40 \\
(0.72-2.72)\end{array}$ & $45 / 278$ & $\begin{array}{l}1.23 \\
(0.75-2.03)\end{array}$ & $\begin{array}{l}0.96 \\
(0.58-1.60)\end{array}$ \\
\hline $\log _{2}$ & & $\begin{array}{l}1.31 \\
(1.13-1.52)\end{array}$ & $\begin{array}{l}1.20 \\
(1.03-1.41)\end{array}$ & & $\begin{array}{l}1.40 \\
(1.09-1.80)\end{array}$ & $\begin{array}{l}1.21 \\
(0.91-1.59)\end{array}$ & & $\begin{array}{l}1.27 \\
(1.06-1.53)\end{array}$ & $\begin{array}{l}1.19 \\
(0.98-1.44)\end{array}$ \\
\hline \multicolumn{10}{|l|}{ TYMS } \\
\hline$\leq$ Median & $35 / 469$ & 1.00 & 1.00 & $19 / 282$ & 1.00 & 1.00 & 16/187 & 1.00 & 1.00 \\
\hline > Median & $76 / 469$ & $\begin{array}{l}1.93 \\
(1.27-2.92)\end{array}$ & $\begin{array}{l}1.11 \\
(0.67-1.84)\end{array}$ & $23 / 183$ & $\begin{array}{l}1.70 \\
(0.91-3.18)\end{array}$ & $\begin{array}{l}0.65 \\
(0.29-1.47)\end{array}$ & $53 / 286$ & $\begin{array}{l}2.09 \\
(1.18-3.68)\end{array}$ & $\begin{array}{l}1.50 \\
(0.77-2.90)\end{array}$ \\
\hline $\log _{2}$ & & $\begin{array}{l}1.37 \\
(1.15-1.64)\end{array}$ & $\begin{array}{l}1.04 \\
(0.83-1.30)\end{array}$ & & $\begin{array}{l}1.38 \\
(1.02-1.85)\end{array}$ & $\begin{array}{l}0.84 \\
(0.61-1.15)\end{array}$ & & $\begin{array}{l}1.34 \\
(1.06-1.69)\end{array}$ & $\begin{array}{l}1.08 \\
(0.80-1.46)\end{array}$ \\
\hline
\end{tabular}


Table 2 Gene expression and risk of recurrence, overall and by race, from CBCS Phase 3, 2008-2013 (Continued)

\begin{tabular}{|c|c|c|c|c|c|c|c|c|c|}
\hline \multirow[b]{2}{*}{ Gene } & \multicolumn{3}{|c|}{ Overall $(n=938)$} & \multicolumn{3}{|l|}{ White $(n=465)$} & \multicolumn{3}{|l|}{ Black $(n=473)$} \\
\hline & Recurrence/n & $\mathrm{HR}^{\mathrm{b}}(95 \% \mathrm{Cl})$ & $\overline{\operatorname{HR}^{C}(95 \% \mathrm{Cl})}$ & Recurrence/n & $\mathrm{HR}^{\mathrm{b}}(95 \% \mathrm{Cl})$ & $\mathrm{HR}^{\mathrm{C}}(95 \% \mathrm{Cl})$ & Recurrence/n & $\mathrm{HR}^{\mathrm{b}}(95 \% \mathrm{Cl})$ & $\mathrm{HR}^{\mathrm{C}}(95 \% \mathrm{Cl}$ \\
\hline \multicolumn{10}{|l|}{ MRE Score ${ }^{a}$} \\
\hline-8 to -2 & $25 / 367$ & 1.00 & 1.00 & $9 / 207$ & 1.00 & 1.00 & $16 / 160$ & 1.00 & 1.00 \\
\hline-1 to 3 & $36 / 336$ & $\begin{array}{l}1.48 \\
(0.88-2.48)\end{array}$ & $\begin{array}{l}1.14 \\
(0.67-1.94)\end{array}$ & $16 / 169$ & $\begin{array}{l}1.93 \\
(0.83-4.47)\end{array}$ & $\begin{array}{l}1.67 \\
(0.72-3.85)\end{array}$ & $20 / 167$ & $\begin{array}{l}1.18 \\
(0.61-2.30)\end{array}$ & $\begin{array}{l}0.88 \\
(0.44-1.76)\end{array}$ \\
\hline 4 to 8 & $50 / 235$ & $\begin{array}{l}3.03 \\
(1.80-5.07)\end{array}$ & $\begin{array}{l}2.10 \\
(1.22-3.62)\end{array}$ & $17 / 89$ & $\begin{array}{l}4.42 \\
(1.89-10.32)\end{array}$ & $\begin{array}{l}2.88 \\
(1.17-7.11)\end{array}$ & $33 / 146$ & $\begin{array}{l}2.44 \\
(1.29-4.62)\end{array}$ & $\begin{array}{l}1.78 \\
(0.91-3.49)\end{array}$ \\
\hline Trend & & $\begin{array}{l}1.15 \\
(1.09-1.22)\end{array}$ & $\begin{array}{l}1.11 \\
(1.04-1.19)\end{array}$ & & $\begin{array}{l}1.19 \\
(1.08-1.31)\end{array}$ & $\begin{array}{l}1.14 \\
(1.03-1.27)\end{array}$ & & $\begin{array}{l}1.14 \\
(1.05-1.23)\end{array}$ & $\begin{array}{l}1.11 \\
(1.02-1.20)\end{array}$ \\
\hline
\end{tabular}

RNA counts were normalized $\log _{2}$-transformed prior to analysis; analyses exclude women with unknown stage and stage IV breast cancer

Log2 = continuous normalized log2-transformed gene expression

$\mathrm{Cl}$ confidence interval, $\mathrm{HR}$ hazard ratio

${ }^{a}$ Multi-gene race-associated expression (MRE) score based on eight genes with higher scores indicating worse risk or recurrence: for ACOX2 and MUC1, $\leq$ median

$=1$ vs $>$ median $=-1$; for FAM177A1, GSTT2, PSPH, PSPHL, SQLE, and TYMS, $\leq$ median $=-1$ vs $>$ median $=1$

${ }^{\mathrm{b}}$ Adjusted for age, race (black vs. white), and codeset, as appropriate

${ }^{C}$ Adjusted for age, race (black vs. white), codeset, PAM50 subtype (luminal A, luminal B, HER2-enriched, basal-like, or normal-like), and risk of recurrence score with tumor size (ROR-PT; low, medium, or high), as appropriate

aggressive tumors including tumors of high histologic grade, nodal involvement, larger size, $\mathrm{ER}^{-} / \mathrm{HER} 2^{+}$status, and with increased risk of breast cancer recurrence, consistent with prior studies [20]. Applying the criteria proposed by D'Arcy et al. [12] for a disparity-associated gene that: (1) the gene should be differentially expressed by race in the tumor, and (2) the differential expression of a candidate gene should be associated with a difference in breast cancer survival, we identified $S Q L E$ as a disparity-associated gene. $S Q L E$ is located on chromosome 8q24.13, and encodes squalene epoxidase, an enzyme that catalyzes the first oxygenation step in cholesterol synthesis [21]. Given that squalene epoxidase is thought to be one of the rate-limiting enzymes in the cholesterol synthesis pathway, overexpression of SQLE may also result in increased cholesterol bioavailability, which may promote ER-dependent growth and Liver X receptor-dependent metastasis [22]. Furthermore, as prior researchers have hypothesized [20], SQLE expression together with overexpression of other nearby genes including $R A D 21$, which encodes a protein involved in DNA repair, could work to promote a more aggressive cancer phenotype. If $S Q L E$ is confirmed by other studies, these findings provide further evidence for the potential use of statins in adjuvant breast cancer therapy $[23,24]$ as well as the potential for $S Q L E$ inhibition as a novel cancer treatment option [20]. The function of FAM177A1 (family with sequence similarity 177 member A1) [25] and PSPHL (phospherine phosphatase-like) [26] are not well characterized and thus their associations with recurrence are not entirely clear. PSPHL is hypothesized to influence rates of cellular proliferation [27], and therefore could potentially directly impact cancer progression.

This study had several strengths including the large population-based design including the oversampling of young and black women; however, this study had several limitations. First, in our analyses of breast cancer recurrence, the proportion of women with at least one recurrence was relatively small (10\%); however, ours is the largest study conducted to date on the topic and provides results consistent with previous studies. Second, a limitation of this research is that we cannot establish the mechanism for higher expression levels (i.e., we cannot distinguish between expression changes that are due to differentiation state or cell lineage versus those that are due to tumor-specific mutations). We also note that some of the genes had prognostic value only within one subtype. For example, genes that tend to be strongly associated with proliferation, such as MUC1 and TYMS, tended to have more prognostic value among luminal breast cancers where proliferation status is variable; very few basal-like breast cancers have low proliferation and therefore proliferation genes often do not provide prognostic value. Third, given prior reports of higher expression of $C R Y B B 2$ among black women compared with white women $[7-9,11,12]$, we were a priori interested in including $C R Y B B 2$ in our analyses; unfortunately, we were unable to examine expression of this gene due to a large amount of missing data. Future studies should continue to examine CRYBB2 expression for its potential relevance as a disparity-associated gene. Finally, in this study we did not compare gene expression in tumor tissue to normal or adjacent-normal tissue; however, in our previous work [12] we observed that patterns of expression, comparing normal to tumor, were similar between black and white women. This suggests that differences in cellular composition between black and white women are not responsible for the racial differences in $M U C 1$ expression.

\section{Conclusions}

In summary, we validated previously observed racial differences in the expression of several genes using a large population-based study. Of the genes that were differentially expressed by race, high expression of one gene, 
SQLE, was also associated with an increased risk of breast cancer recurrence and thus may be a potential disparity-associated gene. Among women with the more favorable $\mathrm{ER}^{+} / \mathrm{HER} 2^{-}$breast cancer subtype, the multigene race-associated score comprised of all eight genes was associated with a $15 \%$ increase in risk of recurrence among black but not white women. We conclude that racial differences in gene expression may contribute to the survival disparity observed between black and white women diagnosed with breast cancer.

\section{Additional file}

Additional file 1: Table S1. Gene expression by participant and clinical characteristics from CBCS Phase 3, 2008-2013. Table S2. RNA counts overall and by race and estrogen receptor (ER) status from CBCS Phase 3, 2008-2013. Table S3. Gene expression and risk of recurrence among women with $\mathrm{ER}^{+} / \mathrm{HER}^{-}$breast cancer from CBCS Phase 3, 2008-2013. (DOCX $81 \mathrm{~kb})$

\section{Abbreviations \\ ACOX2: Acyl-CoA oxidase 2; CBCS3: Carolina Breast Cancer Study Phase 3; $\mathrm{Cl}$ : Confidence interval; CRYBB2: Crystallin beta B2; ER: Estrogen receptor; FAM177A1: Family with sequence similarity 177 member A1; GSTT2: Glutathione S-transferase theta 2; HR: Hazard ratio; MRE: Multi-gene race-associated expres- sion; MUC1: Mucin 1, cell surface associated; PR: Progesterone receptor; PSPH: Phosphoserine phosphatase; PSPHL: Phosphoserine phosphatase pseudogene 1; ROR: Risk of recurrence; ROR-P: Risk of recurrence score with proliferation; ROR-PT: Risk of recurrence score with tumor size; SQLE: Squalene epoxidase; TYMS: Thymidylate synthetase}

\section{Acknowledgements}

We are grateful to CBCS participants and study staff.

\section{Funding}

This study was funded by grants from the National Institutes of Health (U01 CA179715 and U54 CA156733), SPORE in Breast Cancer (P50 CA058223), the National Cancer Institute (P01CA151135), and the National Institute of Environmental Health Sciences (T32 ES007018)

\section{Availability of data and materials}

Not applicable.

\section{Authors' contributions}

XS and MAT were involved in the design of the study. XS, ELK, LO, AFO, and MAT were involved with the acquisition and interpretation of data. HP conducted the analyses and drafted the manuscript. JMF, CRW, and CMP, were involved with interpretation of the data. All authors read and approved the final manuscript.

\section{Ethics approval and consent to participate}

This study was approved by the Institutional Review Board of the University of North Carolina (UNC, Chapel Hill, NC). All participants gave informed consent before they entered the study.

\section{Consent for publication}

Not applicable.

\section{Competing interests}

CMP is an equity stock holder, and Board of Director Member, of BioClassifier LLC and GeneCentric Diagnostics. CMP is also listed as an inventor on a patent application for the PAM50 assay. All other authors declare that they have no competing interests.

\section{Publisher's Note}

Springer Nature remains neutral with regard to jurisdictional claims in published maps and institutional affiliations.

\section{Author details}

'Division of Epidemiology \& Biostatistics, Graduate School of Public Health, San Diego State University, 5500 Campanile Drive, Hardy Tower Room 168, San Diego, CA, USA. ²Department of Epidemiology, University of North Carolina at Chapel Hill, Campus Box 7435, Chapel Hill, NC 27599, USA. ${ }^{3}$ Department of Biological and Biomedical Sciences, North Carolina Central University, Durham, NC, USA. ${ }^{4}$ Department of Genetics, University of North Carolina at Chapel Hill, Chapel Hill, NC, USA.

Received: 16 August 2017 Accepted: 7 November 2017

Published online: 11 December 2017

\section{References}

1. Ravdin PM, Cronin KA, Howlader N, Berg CD, Chlebowski RT, Feuer EJ, et al. The decrease in breast-cancer incidence in 2003 in the United States. N Engl J Med. 2007;356:1670-4.

2. Smigal C, Jemal A, Ward E, Cokkinides V, Smith R, Howe HL, et al. Trends in breast cancer by race and ethnicity: update 2006. CA Cancer J Clin. 2006;56:168-83.

3. Daly B, Olopade Ol. A perfect storm: how tumor biology, genomics, and health care delivery patterns collide to create a racial survival disparity in breast cancer and proposed interventions for change. CA Cancer J Clin. 2015;65:221-38

4. Carey LA, Perou CM, Livasy CA, Dressler LG, Cowan D, Conway K, et al. Race, breast cancer subtypes, and survival in the Carolina Breast Cancer Study. JAMA. 2006;295:2492-502.

5. O'Brien KM, Cole SR, Tse C-K, Perou CM, Carey LA, Foulkes WD, et al. Intrinsic breast tumor subtypes, race, and long-term survival in the Carolina Breast Cancer Study. Clin Cancer Res. 2010;16:6100-10.

6. Troester MA, Sun X, Allott EH, Geradts J, Cohen SM, Tse C-K, et al. Racial differences in PAM50 subtypes in the Carolina Breast Cancer Study. J Natl Cancer Inst. 2018;110:djx135.

7. Huo D, Hu H, Rhie SK, Gamazon ER, Cherniack AD, Liu J, et al. Comparison of breast cancer molecular features and survival by African and European ancestry in the Cancer Genome Atlas. JAMA Oncol. 2017;144:689-99.

8. Stewart PA, Luks J, Roycik MD, Sang Q-XA, Zhang J. Differentially expressed transcripts and dysregulated signaling pathways and networks in African American breast cancer. PLoS One. 2013:8:e82460.

9. Martin DN, Boersma BJ, Yi M, Reimers M, Howe TM, Yfantis HG, et al. Differences in the tumor microenvironment between African-American and European-American breast cancer patients. PLoS One. 2009;4:e4531.

10. Grunda JM, Steg AD, He Q, Steciuk MR, Byan-Parker S, Johnson MR, et al. Differential expression of breast cancer-associated genes between stageand age-matched tumor specimens from African- and Caucasian-American women diagnosed with breast cancer. BMC Res Notes. 2012;5:248.

11. Field LA, Love B, Deyarmin B, Hooke JA, Shriver CD, Ellsworth RE. Identification of differentially expressed genes in breast tumors from African American compared with Caucasian women. Cancer. 2012;118:1334-44.

12. D'Arcy M, Fleming J, Robinson WR, Kirk EL, Perou CM, Troester MA. Raceassociated biological differences among luminal A breast tumors. Breast Cancer Res Treat. 2015;152:437-48.

13. Newman B, Moorman PG, Millikan R, Qaqish BF, Geradts J, Aldrich TE, et al. The Carolina Breast Cancer Study: integrating population-based epidemiology and molecular biology. Breast Cancer Res Treat. 1995;35:51-60.

14. Geiss GK, Bumgarner RE, Birditt B, Dahl T, Dowidar N, Dunaway DL, et al. Direct multiplexed measurement of gene expression with color-coded probe pairs. Nat Biotechnol. 2008;26:317-25.

15. Parker JS, Mullins M, Cheang MCU, Leung S, Voduc D, Vickery T, et al. Supervised risk predictor of breast cancer based on intrinsic subtypes. J Clin Oncol. 2009:27:1160-7.

16. Rakha EA, Boyce RWG, Abd El-Rehim D, Kurien T, Green AR, Paish EC, et al, Expression of mucins (MUC1, MUC2, MUC3, MUC4, MUC5AC and MUC6) and their prognostic significance in human breast cancer. Mod Pathol. 2005; 18:1295-304.

17. Wesseling J, van der Valk SW, Hilkens J. A mechanism for inhibition of Ecadherin-mediated cell-cell adhesion by the membrane-associated mucin episialin/MUC1. Mol Biol Cell. 1996;7:565-77. 
18. Wei $\mathrm{X}, \mathrm{Xu}$ H, Kufe D. MUC1 oncoprotein stabilizes and activates estrogen receptor a. Mol Cell. 2006;21:295-305.

19. Rummel S, Penatzer CE, Shriver CD, Ellsworth RE. PSPHL and breast cancer in African American women: causative gene or population stratification? BMC Genet. 2014;15:1-11.

20. Brown DN, Caffa I, Cirmena G, Piras D, Garuti A, Gallo M, et al. Squalene epoxidase is a bona fide oncogene by amplification with clinical relevance in breast cancer. Sci Rep. 2016;6:19435.

21. NCBI. SQLE squalene epoxidase [Homo sapiens (human)]. 2017. https:// www.ncbi.nlm.nih.gov/gene/6713. Accessed 1 Jan 2017.

22. Nelson ER, Wardell SE, Jasper JS, Park S, Suchindran S, Howe MK, et al. 27-Hydroxycholesterol links hypercholesterolemia and breast cancer pathophysiology. Science (80-). 2013;342:1094-8.

23. Buchwald H. Cholesterol inhibition, cancer, and chemotherapy. Lancet. 1992:339:1154-6.

24. Ahern TP, Lash TL, Damkier P, Christiansen PM, Cronin-Fenton DP. Statins and breast cancer prognosis: evidence and opportunities. Lancet Oncol. 2014;15:e461-8.

25. NCBI. FAM177A1 family with sequence similarity 177 member A1 [Homo sapiens (human)]. 2017. https://www.ncbi.nlm.nih.gov/gene/283635. Accessed 1 Jan 2017.

26. NCBI. PSPHP1 phosphoserine phosphatase pseudogene 1 [Homo sapiens (human)]. 2017. https:/www.ncbi.nlm.nih.gov/gene/8781. Accessed 1 Jan 2017.

27. Planitzer SA, Machl AW, Rueckels M, Kubbies M. Identification of a novel cDNA overexpressed in Fanconi's anemia fibroblasts partially homologous to a putative L-3-phosphoserine-phosphatase. Gene. 1998;210:297-306.

\section{Submit your next manuscript to BioMed Central} and we will help you at every step:

- We accept pre-submission inquiries

- Our selector tool helps you to find the most relevant journal

- We provide round the clock customer support

- Convenient online submission

- Thorough peer review

- Inclusion in PubMed and all major indexing services

- Maximum visibility for your research

Submit your manuscript at www.biomedcentral.com/submit

) Biomed Central 